\title{
Pengaruh Salinitas dan Limbah Cair Tahu pada Konsentrasi yang Berbeda Terhadap Pertumbuhan Mikroalga Botryococcus braunii Kutzing
}

\section{The Effect of Salinity and Tofu Liquid Waste on the Different Concentration of Microalgae Botryococcus braunii Kutzing Growth}

\author{
Savira Amelia Putri ${ }^{1}$, Riche Hariyati ${ }^{1 *}$, dan Tri Retnaningsih Soeprobowati ${ }^{1,2}$ \\ ${ }^{1}$ Program Studi Biologi, Fakultas Sains dan Matematika, Universitas Diponegoro \\ Jl. Prof. Soedarto, SH, Tembalang, Semarang 50275, Indonesia \\ ${ }^{2}$ Sekolah Pasca Sarjana, Universitas Diponegoro \\ Jl. Imam Bardjo, SH, Pleburan, Semarang 50241, Indonesia \\ *Email : riche.hariyati@gmail.com
}

Diterima 26 Februari 2021 / Disetujui 26 Juli 2021

\begin{abstract}
ABSTRAK
Pertumbuhan mikroalga Botryococcus braunii Kutzing dipengaruhi oleh faktor lingkungan berupa salinitas, suhu, pH, oksigen terlarut (DO), intensitas cahaya dan nutrisi pada media kultivasi. Penelitian ini bertujuan untuk mengkaji pengaruh salinitas dan limbah cair tahu terhadap pertumbuhan mikroalga $B$. braunii. Perlakuan yang dilakukan dalam penelitian ini yaitu konsentrasi limbah cair tahu $10 \%$ dengan salinitas $15 \%$ $\left(\mathrm{L}_{10} \mathrm{~S}_{15}\right)$; limbah cair tahu $10 \%$ dengan salinitas $20 \%\left(\mathrm{~L}_{10} \mathrm{~S}_{20}\right)$; limbah cair tahu $10 \%$ dengan salinitas $25 \%$ o $\left(\mathrm{L}_{10} \mathrm{~S}_{25}\right)$; limbah cair tahu $20 \%$ dengan salinitas $15 \%$ o $\left(\mathrm{L}_{20} \mathrm{~S}_{15}\right)$; limbah cair tahu $20 \%$ dengan salinitas $20 \%$ $\left(\mathrm{L}_{20} \mathrm{~S}_{20}\right)$; limbah cair tahu $20 \%$ dengan salinitas $25 \%\left(\mathrm{~L}_{20} \mathrm{~S}_{25}\right)$; limbah cair tahu $30 \%$ dengan salinitas $15 \%$ o $\left(\mathrm{L}_{30} \mathrm{~S}_{15}\right)$; limbah cair tahu $30 \%$ dengan salinitas $20 \%$ o $\left(\mathrm{L}_{30} \mathrm{~S}_{20}\right)$; dan limbah cair tahu $30 \%$ dengan salinitas $25 \%$ o $\left(\mathrm{L}_{30} \mathrm{~S}_{25}\right)$. Pengamatan yang dilakukan meliputi kepadatan sel dan faktor lingkungan berupa salinitas, suhu, $\mathrm{pH}$, oksigen terlarut, serta kadar $\mathrm{N}$ dan $\mathrm{P}$ total. Data yang diperoleh diolah menggunakan metode analisis sidik ragam (ANOVA) yang dilanjutkan dengan uji Duncan. Hasil penelitian menunjukkan kepadatan sel tertinggi didapatkan pada perlakuan $\mathrm{L}_{10} \mathrm{~S}_{25}$ dengan rata-rata kepadatan sel $313 \times 10^{4} \mathrm{sel} / \mathrm{ml}$. Secara umum, semakin tinggi limbah cair tahu yang diberikan maka kepadatan sel mikroalga akan semakin rendah.
\end{abstract}

Kata kunci: Botryococcus braunii, limbah cair tahu, kepadatan sel, kadar lipid.

\begin{abstract}
The growth of the Botryococcus braunii Kutzing microalgae is influenced by environmental factors such as salinity, temperature, $\mathrm{pH}$, dissolved oxygen (DO), light intensity, and nutrients in the cultivation medium. This research aims to examine the effect of salinity and tofu liquid waste on the growth of B. braunii microalgae. The treatment carried out in this research was the concentration of tofu liquid waste of $10 \%$ with salinity $15 \%\left(\mathrm{~L}_{10} \mathrm{~S}_{15}\right)$; tofu liquid waste of $10 \%$ with salinity $20 \%\left(\mathrm{~L}_{10} \mathrm{~S}_{20}\right)$; tofu liquid waste of $10 \%$ with salinity $25 \%\left(\mathrm{~L}_{10} \mathrm{~S}_{25}\right)$;); tofu liquid waste of $20 \%$ with salinity $15 \%\left(\mathrm{~L}_{20} \mathrm{~S}_{15}\right)$; tofu liquid waste of $20 \%$ with salinity $20 \%$ o $\left(\mathrm{L}_{20} \mathrm{~S}_{20}\right)$; tofu liquid waste of $20 \%$ with salinity $25 \%\left(\mathrm{~L}_{20} \mathrm{~S}_{25}\right)$; tofu liquid waste of $30 \%$ with salinity $15 \% 0\left(\mathrm{~L}_{30} \mathrm{~S}_{15}\right)$; tofu liquid waste of $30 \%$ with salinity $20 \%\left(\mathrm{~L}_{30} \mathrm{~S}_{20}\right)$; and tofu liquid waste of $30 \%$ with salinity $25 \% 0\left(\mathrm{~L}_{30} \mathrm{~S}_{25}\right)$. The observations made included cell density and environmental factors such as salinity, temperature, $\mathrm{pH}$, dissolved oxygen, and total $\mathrm{N} \& \mathrm{P}$ levels. The data that has been obtained then analyzed using the analysis of variance method (ANOVA) followed by the Duncan test. The results showed that the highest cell density was found in $\mathrm{L}_{10} \mathrm{~S}_{25}$ treatment with an average cell density of $313 \times 10^{4} \mathrm{sel} / \mathrm{ml}$. In general, the higher the tofu liquid waste given, the lower the density of microalgae cells will be.
\end{abstract}

Keywords : Botryococcus braunii, tofu liquid waste, cell density, lipid levels 


\section{PENDAHULUAN}

Botryococcus braunii merupakan alga sel tunggal berwarna hijau, banyak dijumpai di perairan danau, tambak ataupun perairan payau sampai laut (Metzger \& Largeau, 2005). Kandungan klorofil (zat hijau daun) Botryococcus braunii mencapai $\pm 1,5-2,8 \%$, terdiri dari klorofil $a, b$, dan $c$, sehingga di permukaan perairan tampak berwarna hijau-coklat kekuningan. Botryococcus braunii memiliki inti sel dengan ukuran $\pm 15-20 \mu \mathrm{m}$ dan berkoloni, bersifat nonmotil dan setiap pergerakannya sangat dipengaruhi oleh arus perairan (Kabinawa, 2008). Pertumbuhan Botryococcus braunii dipengaruhi oleh beberapa faktor, yaitu pengaruh intensitas cahaya, konsentrasi nutrisi, serta waktu panen (Sari dkk, 2013).

Industri pembuatan tahu terutama yang berskala rumahan biasanya tidak memperhatikan pengolahan limbah buangannya. Hal ini dapat memunculkan masalah pencemaran lingkungan yang disebabkan oleh pembusukan limbah tahu tersebut. Padahal limbah dari pengolahan tahu tersebut masih memiliki kandungan nutrisi yang dapat dimanfaatkan.

Limbah tahu masih mengandung protein dan lemak sekitar 40\%-60\% (226.06 mg/L sampai $434.78 \mathrm{mg} / \mathrm{L}$ ), karbohidrat sekitar 25\%-50\%, serta nitrat dan fosfat (Anggada dkk., 2019). Menurut Johari (1999), terdapat unsur-unsur hara makro dan mikro yang dibutuhkan bagi pertumbuhan mikroalga antara lain N, P, K, dan Mg. Sedangkan menurut Rahmat dkk. (2013) air dadih (whey) tahu memiliki kandungan air $(99,34 \%)$, protein $(1,73 \%)$, lemak $(0,63 \%)$, abu $(0,11 \%)$ dan nitrogen $(0,05 \%)$.

Berdasarkan kandungan nutrisi yang masih terdapat pada limbah cair tahu, maka pemanfaatannya sebagai medium alternatif pertumbuhan mikroalga merupakan salah satu bentuk pemecahan masalah limbah cair tahu. Cara ini memiliki banyak keunggulan diantaranya adalah penanganannya yang mudah dan murah (Rahmat dkk, 2013).

\section{METODE PENELITIAN}

Penelitian ini dilaksanakan pada bulan Juli 2018 sampai dengan bulan Agustus 2018 di Laboratorium Ekologi dan Biosistematika, Departemen Biologi Fakultas Sains dan Matematika, Universitas Diponegoro. Alat yang digunakan pada penelitian ini yaitu bejana kultur dengan volume 1 liter, aerator, lampu TL dengan tegangan 40 watt, mikroskop, hemositometer, hand counter, pipet tetes, DO meter, $\mathrm{pH}$ meter, spektofotometer, tabung reaksi, cuvet, pipet tetes, cawan petri dan timbangan analitik

Bahan yang digunakan dalam penelitian ini adalah bibit mikroalga $B$. braunii yang diperoleh dari Laboratorium Balai Pengembangan Budidaya Air Payau (BBPBAP) Jepara. Bahan lainnya yaitu tawas, natrium hipoklorit $(\mathrm{NaClO})$, alkohol, air laut dan air tawar steril, limbah cair tahu, pupuk walne, methanol, kloroform, dan akuades.

\section{Rancangan Penelitian}

Penelitian dilakukan dengan metode rancangan faktorial. Perlakuan yang dilakukan dalam penelitian ini yaitu konsentrasi limbah cair tahu $10 \%$ dengan salinitas $15 \%$ o $\left(\mathrm{L}_{10} \mathrm{~S}_{15}\right)$; limbah cair tahu $10 \%$ dengan salinitas $20 \%\left(\mathrm{~L}_{10} \mathrm{~S}_{20}\right)$; limbah cair tahu $10 \%$ dengan salinitas $25 \%$ o $\left(\mathrm{L}_{10} \mathrm{~S}_{25}\right)$; limbah cair tahu $20 \%$ dengan salinitas $15 \%$ ( $\left(\mathrm{L}_{20} \mathrm{~S}_{15}\right)$; limbah cair tahu $20 \%$ dengan salinitas 20\%o $\left(\mathrm{L}_{20} \mathrm{~S}_{20}\right)$; limbah cair tahu $20 \%$ dengan salinitas $25 \%$ o $\left(\mathrm{L}_{20} \mathrm{~S}_{25}\right)$; limbah cair tahu $30 \%$ dengan salinitas $15 \%$ o $\left(\mathrm{L}_{30} \mathrm{~S}_{15}\right)$; limbah cair tahu $30 \%$ dengan salinitas $20 \%$ o $\left(\mathrm{L}_{30} \mathrm{~S}_{20}\right)$; dan limbah cair tahu 30\% dengan salinitas $25 \%$ $\left(\mathrm{L}_{30} \mathrm{~S}_{25}\right)$.

\section{Parameter yang Diamati}

Parameter yang diamati pada penelitian ini adalah kepadatan populasi jenis mikroalga $B$. braunii pada salinitas dan konsentrasi limbah cair tahu yang berbeda, laju pertumbuhan mikroalga, serta total lipid yang terkandung pada mikroalga. Diamati pula parameter abiotik pada kultur yaitu berupa oksigen terlarut (DO), $\mathrm{pH}$, salinitas, $\mathrm{N}$ dan $\mathrm{P}$, serta suhu media kultur. 


\section{Sterilisasi Alat}

Sterilisasi alat dilakukan dengan merendam bejana kultur selama 60 menit dalam air yang sudah dicampur dengan larutan natrium hipoklorit $(\mathrm{NaOCl})$ selama 60 menit. Setelah itu bejana kultur dibilas dengan air kemudian dibiarkan hingga kering.

\section{Persiapan Media Kultur}

Persiapan media kultur dilakukan dengan merebus air tawar, air laut dan limbah cair tahu agar steril. Air laut kemudian diturunkan salinitasnya hingga 25 ppt lalu dimasukkan ke tiap bejana. Limbah cair tahu selanjutnya disaring untuk menghilangkan kotoran yang tersisa. Setelah itu dilakukan pembuatan konsentrasi limbah cair tahu untuk masing-masing perlakuan.

\section{Kultur Mikroalga}

Media kultur mikroalga dibuat stabil pada suhu $30^{\circ} \mathrm{C}$ dan $\mathrm{pH}$ 6-7. Pencahayaan dan aerasi diberikan pada bejana kultur selama 24 jam. Bibit $B$. braunii didapatkan dari Balai Besar Pengembangan Budidaya Air Payau (BBPBAP) Jepara yang telah dikultur sebelumna dalam media air laut dengan konsentrasi sel 100.000-200.000 $\mathrm{sel} / \mathrm{ml}$ pada salinitas $30 \mathrm{ppt}$ (Sari dkk, 2013). Bibit kemudian dimasukkan ke dalam masing-masing bejana kultur.

\section{Mengukur Kualitas Air}

Pengukuran kualitas air dilakukan setiap hari dengan mengukur kadar $\mathrm{pH}$, salinitas, suhu, dan oksigen terlarut (DO). Kadar $\mathrm{N}$ dan $\mathrm{P}$ juga diukur di hari pertama dan hari terakhir penelitian.

\section{Menghitung Kepadatan Populasi}

Penghitungan kepadatan populasi dilakukan setiap 24 jam sekali menggunakan hemositometer, dimulai $t_{0}$ (hari ke-0) hingga $t_{n}$ (hari ke-n). Hasil yang didapat kemudian dihitung menggunakan rumus, Kepadatan $=\mathrm{N} \times 10^{4} \mathrm{sel} / \mathrm{ml}$, dengan $\mathrm{N}=$ jumlah mikroalga yang diamati (Isnansetyo dan Kurniastuti,1995).

\section{Pemanenan Mikroalga}

Pemanenan dilakukan dengan menambahkan tawas (Al2(SO4)3) ke media, kemudian dilakukan pengadukan cepat selama 1 menit dilanjutkan pengadukan lambat selama 15 menit (Hidayati dkk, 2015).

\section{Analisis Data}

Dilakukan analisa statistika yaitu analisis sidik ragam (ANOVA) pada taraf signifikansi 5\%, jika terdapat hasil yang berbeda nyata antar perlakuan maka akan dianalisis lanjut dengan uji Beda Nyata Terkecil (BNT).

\section{HASIL DAN PEMBAHASAN}

\section{Kualitas Air Media Kultur}

Kualitas air berupa $\mathrm{pH}$, salinitas, oksigen terlarut (DO) dan suhu pada penelitian ini diamati setiap hari untuk mengontrol agar terus berada pada rentang optimum. Hasil pengamatan kualitas air selama penelitian disajikan dalam tabel 1 . Kisaran $\mathrm{pH}$ pada media kultivasi $B$. braunii berada pada kisaran 6-8,5. Kisaran ini masih merupakan kisaran $\mathrm{pH}$ optimum untuk pertumbuhan $B$. braunii tanpa menghambat aktivitas petumbuhan selnya. Menurut Kawaroe dkk. (2010), kisaran pH optimum untuk pertumbuhan alga hijau adalah 79. Kisaran $\mathrm{pH}$ pada media kultur juga dikontrol setiap hari agar perubahan $\mathrm{pH}$ pada media tidak drastis dan menghambat pertumbuhan mikroalga. Menurut Soeprobowati dan Hariyati (2013), perubahan nilai $\mathrm{pH}$ yang drastis dapat mempengaruhi kerja enzim dan menghambat proses fotositesis dan pertumbuhan mikroalga.

Kadar DO dan suhu pada media kultivasi diamati dengan menggunakan alat DO meter. Hasil pengamatan DO selama kultivasi berkisar antara 8,46 mg/l. Yusuf (2014), kadar minimal oksigen terlarut (DO) yang diperlukan oleh mikroalga adalah $3,0 \mathrm{mg} / \mathrm{l}$ agar dapat dimanfaatkan oleh organisme perairan untuk proses respirasi dan menguraikan zat organik menjadi zat anorganik. Rata-rata suhu media berada pada $27,8^{\circ} \mathrm{C}$. Kisaran suhu tersebut masih dalam kisaran oprimal bagi pertumbuhan $B$. 
braunii. peningkatan suhu dapat mempengaruhi kenaikan proses metabolisme pada mikroalga.
Peningkatan suhu yang terlalu tinggi dapat menyebabkan kematian sel.

Tabel 1. Kualitas Air Media Kultur

\begin{tabular}{cc}
\hline Parameter & Kadar \\
\hline $\mathrm{pH}$ & 7,6 \\
$\mathrm{DO}$ & $8,46 \mathrm{mg} / \mathrm{l}$ \\
Suhu & $27,8^{\circ} \mathrm{C}$ \\
\hline
\end{tabular}

Tabel 2. Hasil pengukuran $\mathrm{N}$ dan $\mathrm{P}$ pada media kultur

\begin{tabular}{lcccccc}
\hline & \multicolumn{3}{c}{ Kadar N dan P $(\mathrm{mg} / \mathrm{l})$} & \multicolumn{3}{c}{ Persentase penurunan } \\
\cline { 2 - 7 } Perlakuan & $\mathrm{N}$ awal & $\mathrm{P}$ awal & $\mathrm{N}$ akhir & $\mathrm{P}$ akhir & $\mathrm{N}(\%)$ & $\mathrm{P}(\%)$ \\
\hline Kontrol & 7,34 & 7,46 & 6,48 & 6,16 & 11,58 & 17,42 \\
$\mathrm{~L}_{10} \mathrm{~S}_{25}$ & 5,34 & 2,45 & 4,36 & 1,98 & 18,35 & 19.18 \\
$\mathrm{~L}_{30} \mathrm{~S}_{15}$ & 10,73 & 8,42 & 9,23 & 6,32 & 13,97 & 24,94 \\
\hline
\end{tabular}

Kadar $\mathrm{N}$ dan P pada awal kultivasi dan akhir kultivasi juga diukur. Hasil pengukuran $\mathrm{N}$ dan $\mathrm{P}$ dapat dilihat dalam tabel 1.2. Kadar $\mathrm{N}$ dan $\mathrm{P}$ pada perlakuan limbah cair tahu $\mathrm{L}_{30} \mathrm{~S}_{15}$ memiliki jumlah yang tinggi, hal ini dapat menghambat pertumbuhan dari mikroalga yang dikultivasi pada media tersebut. Hal ini dapat dilihat dari kepadatan populasi mikroalganya. Konsentrasi nitrogen yang tinggi akan menghambat pertumbuhan sel, $\mathrm{NH}_{3}$ yang terlalu banyak dalam media kultur akan menjadi racun dan mengakibatkan aktivitas sel terganggu dalam proses metabolisme.

Pengurangan jumlah kadar $\mathrm{N}$ dan $\mathrm{P}$ pada media kultur menandakan bahwa mikroalga dapat memanfaatkan unsur hara yang ada pada media sebagai nutrisi untuk pertumbuhannya. Pada limbah cair tahu terdapat senyawa $\mathrm{N}$ dalam bentuk N-organik, N-nitrit $\left(\mathrm{NO}_{2}{ }^{-}\right), \mathrm{N}$-nitrat $\left(\mathrm{NO}_{3}{ }^{-}\right), \mathrm{N}$ ammonium $\left(\mathrm{NH}_{4}{ }^{+}\right)$. Senyawa nitrat $\left(\mathrm{NO}_{3}{ }^{-}\right)$inilah yang dapat diserap langsung oleh mikroalga, sedangkan $\mathrm{NO}_{2}{ }^{-}$dan $\mathrm{NH}_{4}{ }^{+}$akan dirubah melalui proses nitrifikasi menjadi senyawa $\mathrm{NO}_{3}{ }^{-}$. Pertumbuhan mikroalga menjadi terhambat jika kadar $\mathrm{NH}_{4}{ }^{+}$yang terbentuk sedikit sebagai akibat dari penurunan $\mathrm{NO}_{3}^{-}$dalam medium. Namun, $\mathrm{NH}_{4}{ }^{+}$yang berlebihan akan membuat pertumbuhan menurun karena gugus tersebut sangat beracun yang dapat menghambat pembentukan ATP di kloroplas maupun mitokondria (Zulkifli, 2001).
Kadar fosfor dalam media kultivasi berfungsi untuk menyusun karbohidrat. Menurut Zahara (2003) menyatakan bahwa keberadaan unsur P diperlukan karena unsur ini penting dalam proses transformasi energi dalam proses fotosintesis. Gula terfosforilasi yang kaya energi muncul dalam proses fotosintesis. Fosforilasi adenosin menghasilkan adenosin monofosfat, difosfat, trifosfat (AMP, ADP, ATP).

\section{Kepadatan Populasi B. braunii}

Kepadatan populasi mikroalga $B$, braunii pada penelitian ini dihitung selama sepuluh hari. Grafik pertumbuhan $B$. braunii dapat dilihat pada gambar 1. Kepadatan sel B. braunii pada tiap perlakuan di hari pertama hingga hari kedua cenderung sama. Hal ini dikarenakan mikroalga berada pada tahap fase lag (adaptasi) untuk menyesuaikan diri dengan lingkungannya setelah media kultivasi tersebut diberi limbah cair tahu. Fase lag yang biasa terjadi pada awal kultivasi merupakan fase adaptasi terhadap lingkungan tumbuh yang baru. Menurut Musdalifah (2015), pada fase adaptasi (lag) pertumbuhan sel lambat dikarenakan alokasi energi dipusatkan untuk penyesuaian diri terhadap media kultur yang baru dan untuk pemeliharaan sehingga hanya sebagian kecil energi yang digunakan untuk pertumbuhan. 


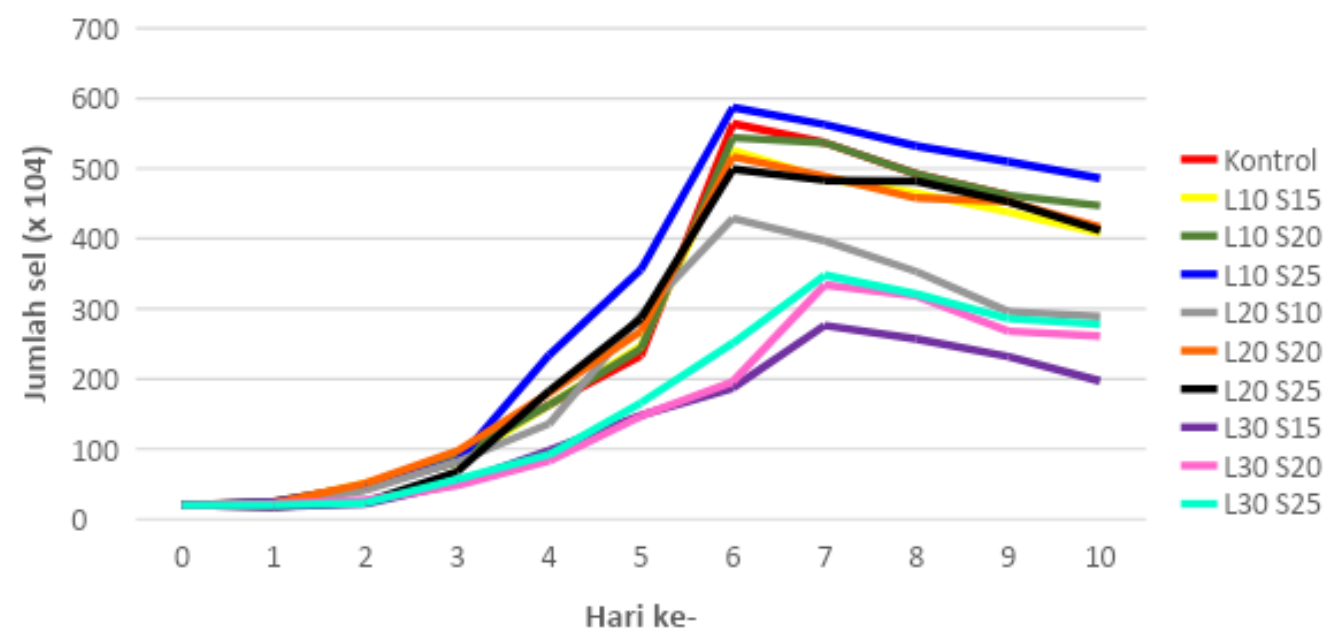

Gambar 1. Kepadatan populasi B. braunii dari hari ke-0 sampai hari ke-10

Setelah mengalami fase adaptasi, kepadatan populasi $B$. braunii rata-rata terus meningkat secara signifikan mulai hari kedua hingga hari keenam. Peningkatan jumlah sel yang cepat ini menandakan bahwa mikroalga berada pada fase eksponensial. Fase eksponensial merupakan fase pertumbuhan dimana mikroalga akan membelah diri dengan aktif yang menyebabkan kepadatan sel meningkat lebih cepat dibandingkan pada fase lainnya.

Hari keenam hingga hari kesepuluh, ratarata grafik kepadatan populasi $B$. braunii mengalami penurunan yang menandakan bahwa mikroalga mulai mengalami kematian sel, sehingga kepadatan sel akan menurun. Hal tersebut didukung oleh hasil penelitian Simamora dkk. (2017) yang menunjukkan bahwa saat memasuki hari kedelapan B. braunii mengalami penurunan kepadatan sel secara geometrik sampai hari kesepuluh. Penurunan kepadatan sel $B$. braunii setelah hari keenam juga disebabkan oleh berkurangnya jumlah nutrisi yang tersedia bagi pertumbuhan mikroalga.

Data hasil pengamatan kepadatan populasi B. braunii kemudian diuji statistik. Hasil uji statistik menunjukkan bahwa perlakuan $\mathrm{L}_{10} \mathrm{~S}_{25}$ merupakan perlakuan yang paling baik terhadap pertumbuhan mikroalga yang ditandai dengan pertabahan jumlah sel. Pertumbuhan mikroalga $B$. braunii pada salinitas $25 \%$ memiliki hasil yang paling optimum dibandingkan pada salinitas $15 \%$ dan 20\%o. Laju pertumbuhan B. braunii pada kontrol dengan salinitas 25\% juga memiliki laju pertumbuhan yang tinggi. Hal tersebut menandakan bahwa salinitas 25\% merupakan salinitas yang cocok bagi pertumbuhan mikroalga $B$. braunii dibandingkan dengan salinitas yang lebih rendah. Hal ini didukung oleh penelitian dari Musdalifah dkk. (2015) yang menyatakan bahwa B. braunii dapat tumbuh dengan baik pada salinitas antara 25-30 ppt, apabila salinitas melebihi rentang pertumbuhan doimungkinkan mikroalga ini tidak dapat mentoleransi sehingga tumbuh dengan tidak baik atau mati.

Perlakuan penambahan limbah cair tahu $10 \%$ memiliki pengaruh yang paling baik dibandingkan dengan perlakuan lain. Hal ini disebabkan karena limbah cair tahu diberikan dalam jumlah yang cukup sehingga mikroalga dapat memanfaatkan nutrisi dalam media dengan baik untuk pertumbuhannya. Hal ini juga membuktikan bahwa limbah cair tahu dapat digunakan sebagai alternatif pengganti pupuk walne serta sebagai salah satu solusi pemanfaatan limbah cair tahu guna mengurangi pembuangan limbah tersebut ke lingkungan.

Hasil dari perlakuan penambahan limbah cair tahu $20 \%$ dan $30 \%$ memiliki laju pertumbuhan yang lebih rendah dibandingkan dengan kontrol dan perlakuan penambahan limbah cair tahu $10 \%$. Rendahnya kepadatan populasi dikarenakan limbah cair tahu yang ditambahkan terlalu banyak dan tidak dapat dimanfaatkan secara efektif oleh mikroalga sehingga akan menghasilkan tumpukan 
bahan organik yang bersifat racun bagi mikroalga dan pada akhirnya dapat menghambat pertumbuhan. Semakin banyak penambahan limbah cair tahu, media kultivasi semakin keruh dan pertumbuhan mikroalga terhambat.

\section{KESIMPULAN}

B. braunii yang diberi perlakuan penambahan limbah cair tahu $10 \%$ memiliki laju pertumbuhan yang optimal, sedangkan laju pertumbuhan yang terendah dimiliki oleh $B$. braunii yang diberi limbah cair tahu $30 \%$. Salinitas $25 \%$ merupakan salinitas optimum untuk pertumbuhan B. braunii. Semakin rendah salinitas yang diberikan, semakin rendah pula laju pertumbuhannya.

\section{DAFTAR PUSTAKA}

Anggada, R. D, Sucahyo, dan S. P. Hastuti. 2019. Pertumbuhan Cacing Tanah (Lumbricus rubellus) dan Komposisi Kompos pada Media yang Diperkaya Limbah Rumah Makan dan Limbah Industri Tahu. Buletin Anatomi dan Fisiologi 4 (2):182-191.

Hidayarti, S., O. Nawansih, dan V. Febiana. 2015. Teknik Pemanenam Mikroalga Nannochloropsis sp. Yang Dikultivasi dalam Media Limbah Cair Karet Remah dengan Flokulan Alumunium Sulfat. Jurnal Teknologi Industri dan Hasil Pertanian 20 (2) : 97-108.

Kabinawa, I.N.K. 2008. Biodiesel energi terbarukan dari mikroalga. Warta Pertamin. (9): 31-35

Kawaroe, M., Prartono T., Sunuddin A., Sari S.W., dan Augustine D,. 2010. Mikroalga: Potensi dan Pemanfaatannya untuk Produksi Bio Bahan Bakar. Bogor: PT. Penerbit IPB Press.

Metzger, P. dan C. Largeau. 2005. Botryococcus braunii: a Rich Source for Hydrocarbons and Related Ether Lipids. Application Microbiology Biotechnology. 5 (66) : 486496.

Musdalifah, Y. Rustam, dan S. Amini. 2015. Kultivasi dan Ekstraksi Minyak dari Mikroalga Botryococcus braunii dan Nannochloropsis sp. BIOMA 11 (1) : 01263552.
Rahmat, T. A., R. D. Dias, dan D. Seotrisnanto. 2013. Kultivasi Botryococcus Braunii Memanfaatkan Air Dadih (Whey) Tahu sebagai Potensi Biofuel. Jurnal Teknologi Kimia dan Industri, 2 (4) : 72-83.

Sari, A. M., H. E. Mayasari, Rachimoellah, dan S. Zulaikah. 2013. Pertumbuhan dan Kandungan Lipida dari Botryococcus Braunii dalam Media Air Laut. Jurnal Teknik Pomits, 2 (1) : 2337-3539.

Sari, I. P. 2011. Pola pertumbuhan Nannochloropsis oculata pada skala laboratorium, intermediet dan masal. Ilmiah Perikanan dan Kelautan. 4(2): 123-127.

Simamora, L. A, Sudarno, dan T. Istirokhatun. 2017. Kultivasi Mikroalga sebagai Metode Pengolahan dalam Menyisihkan Kadar COD dan Amonium pada Limbah Cair Tahu. Jurnal Teknik Lingkungan 6 (1) : 1-14.

Soeprobowati, T. R dan R. Hariyati. 2013. Bioaccumulation of $\mathrm{Pb}, \mathrm{Cd}, \mathrm{Cu}$, and $\mathrm{Cr}$. By Porphyridium cruentum (S.F. Gray) Nageli. International Journal of Marine Science 3(27) : 212-218.

Yusuf, D. M. Pertumbuhan Populasi Mikroalga Spirulina Platensis (Geitler) pada Konsentrasi Logam Berat Tembaga $(\mathrm{Cu})$. Jurnal Biologi 3 (1) : 1-9.

Zulkifli dan Ami, A. 2011. Pengelolaan Limbah Cair Pabrik tahu dengan Rotating Biological Contactor (RBC) pada Skala Laboratorium. Limnotek Vol. VIII No. 1 : 21-34. 